\title{
Kepemilikan Manajerial dan Kepemilikan Institusional Terhadap Kebijakan Hutang Pada Perusahaan Manufaktur di BEI Tahun 2016-2019
}

\author{
Evi Dwi Kartikasari ${ }^{1}$, Arfiana Dewi ${ }^{2 *}$, Muhammad Sulton ${ }^{3}$ \\ Institut Teknologi dan Bisnis Ahmad Dahlan Lamongan \\ evican91@gmail.com,darfiana26@gmail.com, sulton.integration@gmail.com
}

\begin{abstract}
*Penulis Korespondensi
Diajukan : 25 Januari 2022

Disetujui : 27 Januari 2022

Dipublikasi : 29 Januari 2022
\end{abstract}

\begin{abstract}
The company's performance can be seen from financial performance, in addition to the right policies implemented by the company's management. Company policy is closely related to financial performance, namely debt policy. Debt policy is a funding decision from external parties taken by the company to develop the company, expand the capital, business and fund the company's operations. The use of debt can increase the risk of the company, when the company is unable to pay off its debt then threatened liquidity, so management must take the right decision to minimize the risk borne by the company. Debt can help overcome funding problems, but it is necessary to consider the risk of bankruptcy on the use of large amounts of debt. The purpose of this study is to find out the influence of managerial ownership and institutional ownership on the debt policies of Manufacturing companies listed in the IDX in 2016, 2017, 2018,2019. This type of research is descriptive with a quantitative approach focusing on hypothesis testing. This type of data uses secondary data in the form of annual report data of manufacturing companies listed on the Indonesia stock exchange in 2016-2019 taken from the IDX.co.id website. Data analysis techniques use multiple linear regression analysis to determine the relationship between independent variables and dependent variables using SPSS software tools. The stages performed in the analysis are conducting classical assumption tests, multiple linear regression analysis, hypothesis testing, and determination coefficient tests.
\end{abstract}

Keywords: Good Corporate Governance, Debt Policy

\section{PENDAHULUAN}

Kelangsungan hidup perusahaan dapat ditingkatkan dengan meningkatkan kinerja perusahaan tersebut. Kinerja perusahaan yang baik dapat dilihat dari kinerja keuangan perusahaan, selain itu juga dapat dilihat dari kebijakan yang tepat yang dilaksanakan oleh manajemen perusahaan. Kebijakan di dalam perusahaan merupakan cerminan langkah manajerial untuk mengambil keputusan. Kebijakan perusahaan yang ada hubungannya denga kinerja keuangan salah satunya yaitu mengenai kebijakan hutang. Kebijakan hutang merupakan keputusan pendanaan dari pihak eksternal yang diambil oleh perusahaan guna untuk mengembangkan perusahaan, perluasan modal dan usaha serta untuk mendanai operasional perusahaan. Penggunaan hutang dapat meningkatkan risiko perusahaan, karena ketika perusahaan tidak mampu melunasi hutangnya maka akan terancam likuiditasnya, sehingga manajemen harus mampu mengambil keputusan yang sesuai dan tepat untuk meminimalisir risiko yang akan ditanggung oleh perusahaan. Kebijakan hutang merupakan tanggung jawab dari pihak manajer, akan tetapi untuk melaksanakannya harus mempertimbangkan berdasarkan kepentingan pemilik modal yang merupakan bentuk tanggung jawab manajemen terhadap pengelolaan modal yang diserahkan kepadanya. Niken (2017) menyatakan bahwa Kebijakan hutang merupakan keputusan penting yang sangat berpengaruh terhadap kebijakan kondisi suatu perusahaan. Hal ini berkaitan dengan pendanaan yang diperoleh melalui hutang. Hutang dapat sangat membantu dalam mengatasi masalah pendanaan, akan tetapi perlu 
dipertimbangkan risiko akan terjadinya kebangkrutan pada penggunaan hutang dalam jumlah yang besar. Berita yang ditulis oleh Kompasiana.com mengenai posisi hutang luar negeri Indonesia dalam kelompok peminjam dari tahun 2011 - 2016 menunjukkan bahwa hutang perusahaan dari tahun 2011-2016 cenderung mengalami peningkatan. Peningkatan jumlah hutang akan meningkatkan resiko perusahaan. Tingkat jumlah hutang dari tahun 2011-2016 yang terus meningkat, dapat disimpulkan bahwa perusahaan lebih tertarik untuk mendapatkan modal perusahaan dari hutang. Kebijakan hutang yang biasanya diukur dengan Debt to Equity Ratio (DER) merupakan suatu rasio keuangan yang menunjukan proporsi relatif antara ekuitas dan hutang yang digunakan untuk membiayai aset perusahaan. Pemberi pinjaman dan investor biasanya memilih debt to equity ratio yang rendah karena kepentingan mereka lebih terlindungi jika terjadi penurunan bisnis pada perusahaan yang bersangkutan. Perusahaan yang memiliki debt to equity ratio atau rasio hutang terhadap ekuitas yang tinggi mungkin tidak dapat menarik tambahan modal dengan pinjaman dari pihak lain.

Kebijakan hutang dilakukan dengan mempertimbangkan prosentase kepemilikan dalam perusahaan, sehingga faktor yang dapat mempengaruhi kebijakan hutang diantaranya yaitu kepemilikan manajerial dan kepemilikan institusional. Wahidahwati (2002) dalam Alfinur (2016) kepemilikan manajerial adalah pemegang saham dari pihak manajemen yang secara aktif ikut dalam pengambilan keputusan perusahaan (direksi dan komisarias). Pihak manajerial dalam suatu perusahaan adalah pihak yang secara aktif berperan aktif dalam pengambilan keputusan untuk menjalankan perusahaan. Brigham (2005:528), kepemilikan institusional merupakan kepemilikan investasi saham yang dimiliki oleh institusi lain seperti: perusahaan, dana pensiun, reksadana, dan lain lain dalam jumlah yang besar. Tujuan perusahaan dalam melaksanakan kebijakan hutang, tidak lepas dari semakin berkembangnya perusahaan manufaktur yang diikuti dengan persaingan yang semakin ketat. Industri manufaktur di Indonesia di anggap sebagai sektor yang sangat penting, berdasarkan pernyataan Bapak Muhammad Jusuf Kalla (JK) yang dikutip dari CNBC Indonesia Outlook 2019 yaitu pada saat memberikan pidato kunci dalam acara CNBC Indonesia Economic Outlook 2019, JK mengatakan bahwa "Yang bisa memajukan republik ini hanya manufacturing," artinya bahwa yang bisa memajukan ekonomi Indonesia hanyalah industri manufaktur, papar JK yang berlatarbelakang seorang pengusaha, dan Menurut JK, seorang petani dengan tingkat etos kerja paling tinggi pun pendapatannya masih kalah dari seorang buruh yang bekerja di industri manufaktur. Pertumbuhan produksi industri manufaktur besar dan sedang triwulan IV tahun 2019 naik sebesar 3,62\% terhadap triwulan IV tahun 2018. Kenaikan tersebut disebabkan naiknya produksi industri farmasi, produk obat kimia dan obat tradisional, naik 18,58\%. Pertumbuhan produksi industri manufaktur besar dan sedang triwulan IV tahun 2019 naik sebesar 0,09\% terhadap triwulan III 2019. Industri yang mengalami kenaikan produksi tertinggi adalah industri bahan kimia dan barang dari bahan kimia, naik 13,07\%. Industri yang mengalami penurunan terbesar adalah industri komputer, barang elektronik dan optik, turun $11,85 \%$.

Penelitian terdahulu mengenai hubungan kepemilikan manajerial dan kepemilikan institusional terhadap kebijakan hutang telah dilakukan oleh beberapa peneliti dan terdapat hasil yang inkonsistensi. Berdasarkan fenomena yang ada dan Inkonsistensi hasil penelitian dari beberapa penelitian terdahulu serta peneliti berasal dari rumpun ilmu akuntansi yang dalam RIP menyatakan bahwa adanya kebutuhan keterlaksanaan penelitian dosen yang sesuai dengan bidang ilmu, maka hal ini menarik minat peneliti untuk melakukan penelitian dengan tema yang sama.

Tujuan dari penelitian ini yaitu untuk mengetahui pengaruh kepemilikan manajerial dan kepemilikan institusional terhadap kebijakan hutang perusahaan Manufaktur yang terdaftar di BEI Tahun 2016,2017,2018,2019.

\section{Penelitian Terdahulu}

\section{STUDI LITERATUR}

Revi (2017) menyatakan bahwa Kebijakan hutang merupakan salah satu penentu arah pertimbangan dari struktur modal, karena struktur modal perusahaan merupakan perimbangan dari jumlah hutang jangka pendek (permanen), hutang jangka panjang, saham preferen, dan juga saham biasa. Niken (2017) Kebijakan hutang termasuk kebijakan pendanaan perusahaan yang bersumber dari eksternal. Kebijakan ini memiliki dampak pada konflik dan biaya keagenan. Jensen dan 
Meckling (1976) menyatakan bahwa dengan hutang maka perusahaan akan melakukan pembayaran periodik atas bunga dan pokok pinjaman. Kebijakan hutang akan memberikan dampak pada pendisiplinan bagi manajer untuk mengoptimalkan penggunaan dana yang ada. Karena hutang yang cukup besar akan menimbulkan kesulitan keuangan dan atau risiko kebangkrutan.

Larasati (2017) menyatakan bahwa kepemilikan saham oleh institusi dapat menggantikan peranan hutang dalam memonitor manajemen perusahaan. Dengan demikian, semakin besar prosentase saham yang dimiliki oleh institusi akan menyebabkan usaha monitoring menjadi semakin efektif, karena dapat mengendalikan perilaku oportunistik yang dilakukan oleh para manajemen dan memaksa manajemen untuk mengurangi tingkat hutang secara optimal, sehingga akan mengurangi agency cost. Menurut Larasati (2017) menyatakan bahwa kepemilikan institusional merupakan kepemilikan investasi saham yang dimiliki oleh institusi lain seperti: perusahaan, dana pension, reksadana, dll dalam jumlah yang besar.

Penelitian yang dilakukan oleh Eva larasati (2017) menunjukkan bahwa kepemilikan manajerial tidak berpengaruh terhadap kebijakan hutang dan kepemilikan institusional berpengaruh signifikan positif terhadap kebijakan hutang. Niken (2017) menyimpulkan bahwa kepemilikan manajerial dan kepemilikan institusional tidak berpengaruh terhadap kebijakan hutang. Indra (2013) dalam penelitiannya menyimpulkan bahwa kepemilikan manajerial dan kepemilikan institusional berpengaruh terhadap kebijakan hutang. Rizka (2019) menyimpulkan bahwa kepemilikan manajerial tidak berpengaruh terhadap kebijakan hutang, dan kepemilikan institusional berpengaruh signifikan positif terhadap kebijakan hutang.

\section{Kebijakan Hutang (Leverage)}

Kieso et al (2007:96) dalam Jorenza (2015) menjelaskan bahwa kebijakan hutang adalah kebijakan yang diambil perusahaan untuk melakukan pembiayaan melalui hutang. Perusahaan dinilai beresiko apabila memiliki porsi hutang yang besar dalam struktur modal, namun sebaliknya apabila perusahaan menggunakan hutang kecil atau tidak sama sekali maka perusahaan dinilai tidak dapat memanfaatkan tambahan modal eksternal yang dapat meningkatkan operasional perusahaan. Revi (2015) menyatakan bahwa Kebijakan hutang merupakan salah satu penentu arah pertimbangan dari struktur modal, karena struktur modal perusahaan merupakan perimbangan dari jumlah hutang jangka pendek (permanen), hutang jangka panjang, saham preferen, dan juga saham biasa. Niken (2017) Kebijakan hutang termasuk kebijakan pendanaan perusahaan yang bersumber dari eksternal. Kebijakan ini memiliki dampak pada konflik dan biaya keagenan. Jensen dan Meckling (1976) menyatakan bahwa dengan hutang maka perusahaan akan melakukan pembayaran periodik atas bunga dan pokok pinjaman. Kebijakan hutang akan memberikan dampak pada pendisiplinan bagi manajer untuk mengoptimalkan penggunaan dana yang ada. Karena hutang yang cukup besar akan menimbulkan kesulitan keuangan dan atau risiko kebangkrutan

\section{Good corporate governance}

Forum for Corporate Governance in Indonesia (FCGI) mendefinisikan corporate governance sebagai seperangkat peraturan yang mengatur hubungan antara pemegang saham, pengelola perusahaan, pihak kreditur, pemerintah, karyawan, serta para pemegang kepentingan internal dan eksternal lainnya yang berkaitan dengan hak-hak dan kewajiban mereka. Dengan kata lain suatu sistem yang mengendalikan perusahaan. Tujuan corporate governance ialah untuk menciptakan nilai tambah bagi semua pihak yang berkepentingan (stakeholders). "Corporate Governance adalah sistem dan struktur untuk mengelola perusahaan dengan tujuan meningkatkan nilai pemegang saham serta mengakomodasi berbagai pihak yang berkepentingan dengan perusahaan seperti kreditor, supplier, asosiasi usaha, konsumen, pekerja, pemerintah, dan masyarakat luas. ada empat mekanisme corporate governance yang sering dipakai dalam berbagai penelitian mengenai corporate governance yang bertujuan untuk mengurangi konflik keagenan, yaitu komite audit, komisaris independen, kepemilikan institusional, kepemilikan manajerial (Rachmawati dan Triatmoko, 2007 dalam Perdana dan Raharja 2014).

Menurut teori Jensen dan Meckling (1976) semakin besar kepemilikan manajerial maka penggunaan hutang akan semakin menurun. Kepemilikan manajerial merupakan kondisi dimana manajer mempunyai saham perusahaan. Sehingga dalam hal ini manajer sebagai pengelola 
perusahaan juga pemilik perusahaan atau pemegang saham perusahaan. Kepemilikan manajerial dapat diketahui dari besarnya prosentase kepemilikan saham perusahaan dalam laporan keuangan.

Menurut Bushee (Boediono, 2005) menyatakan bahwa kepemilikan institusional memiliki kemampuan untuk mengurangi insentif para manajer yang mementingkan diri sendiri melalui tingkat pengawasan yang intens. Kepemilikan institusional dapat menekan kecenderungan manajemen untuk memanfaatkan discretionary dalam laporan keuangan sehingga memberikan kualitas laba yang dilaporkan. Kepemilikan institusional memiliki kemampuan untuk mengendalikan pihak manajemen melalui proses monitoring secara efektif sehingga mengurangi tindakan manajemen melakukan manajemen laba. Persentase saham tertentu yang dimiliki oleh institusi dapat mempengaruhi proses penyusun laporan keuangan yang tidak menutup kemungkinan terdapat akrualisasi kepentingan pihak manajemen.

\section{METODE}

Jenis penelitian yang digunakan dalam penelitian ini adalah deskriptif dengan pendekatan kuantitatif berfokus pada pengujian hipotesis sesuai dengan model analisis yang ditentukan kemudian mendeskripsikan hasilnya. Dalam penelitian ini, Jenis data yang digunakan adalah data sekunder yaitu berupa data laporan tahunan perusahaan manufaktur yang terdaftar di bursa efek Indonesia tahun 2016-2019 yang diambil (download) dari website perusahaan terkait dan website http://www.idx.co.id.

Tabel 1.

Identifikasi Variabel

\begin{tabular}{|c|c|c|}
\hline No & Variabel & Perhitungan \\
\hline \multicolumn{2}{|c|}{ Variabel Deenden } & DAR $=\frac{\text { Total hutang }}{\text { Asets }}$ X 100\% \\
\hline 1 & Kebijakan hutang & \\
\hline 2 & Kepemilikan Manajerial & KM $=\frac{\text { Saham manajerial }}{\text { Saham beredar }}$ 100\% \\
\hline 3 & Kepemilikan Institusional & KI $=\frac{\text { Saham Institusional }}{\text { Saham beredar }}$ X 100\% \\
\hline
\end{tabular}

Populasi dalam penelitian ini adalah seluruh perusahaan manufaktur yang terdaftar di Bursa Efek Indonesia tahun 2019, yaitu sebanyak 169 perusahaan. Metode pengambilan sampel yang digunakan dalam penelitian ini adalah nonprobability sampling jenis purposive sampling. yang berarti pemilihan sampel berdasarkan kriteria tertentu. Adapun kriteria perusahaan yang dijadikan sampel dijelaskan pada tabel sebagai berikut:

Tabel 2.

Kreteria Pemilihan Sampel

\begin{tabular}{|l|l|c|}
\hline No & Kreteria & $\begin{array}{l}\text { Jumlah } \\
\text { Perusahaan }\end{array}$ \\
\hline 1 & $\begin{array}{l}\text { Perusahaan Manufaktur yang terdaftar di Bursa Efek Indonesia yang } \\
\text { listing pada tahun 2016, 2017, 2018 dan 2019 }\end{array}$ & 169 \\
\hline 2 & $\begin{array}{l}\text { Perusahaan Manufaktur yang tidak menerbitkan laporan keuangan } \\
\text { perusahaan secara lengkap selama tahun 2016,2017, 2018 dan 2019 } \\
\text { melalui website http://www.idx.co.id. }\end{array}$ & $(71)$ \\
\hline 3 & $\begin{array}{l}\text { Perusahaan Manufaktur yang laporan keuangan perusahaan selama tahun } \\
\text { 2017, 2018 dan 2019 dilaporkan menggunakan mata uang non rupiah }\end{array}$ & $(3)$ \\
\hline 4 & Perusahaan Manufaktur dalam sub sektor Rokok & $(4)$ \\
\hline \multicolumn{2}{|l|}{ Jumlah sampel akhir yang memenuhi kreteria } \\
\hline Jumlah Data dalam sampel Penelitian 91 x 4 tahun =364 data penelitian \\
\hline
\end{tabular}

Sampel perusahaan yang dipakai dalam penelitian ini yaitu perusahaan yang memenuhi kreteria diatas sebanyak 91 Perusahaan dengan total data penelitian sebanyak 364 data. 
Metode pengumpulan data yang dipakai dalam penelitian ini menggunakan metode pustaka, kajian internet dan dokumentasi. Metode pengumpulan dilaklukan dengan mengumpulkan data laporan tahunan perusahaan periode penelitian (tahun 2016,2017,2018, dan 2019) kemudian diolah sesuai dengan kebutuhan penelitian dan dianalisis.

Teknik analisis data yang digunakan dalam penelitian ini yaitu analisis regresi linier berganda untuk mengetahui hubungan antara variadel independen dan variabel dependen dengan menggunakan alat bantu software statistik SPSS Ver.25. Tahapan yang dilakukan dalam analisis yaitu dengan melakukan perhitungan semua variabel penelitian, kemudian dilakukan uji asumsi klasik. Setelah itu dilakukan analisis regresi linier berganda, kemudian dilakukan pengujian hipotesis dan uji koefisien determinasi.

\section{HASIL}

Penelitian ini dilakukan dengan menganalisis laporan keuangan tahunan dan annual report perusahaan manufaktur yang terdaftar di Bursa Efek Indonesia pada tahun 2016,2017,2018 dan 2019. Penelitian dilakukan untuk mengetahui pengaruh kepemilikan manajerial dan kepemilikan institusional terhadap kebijakan hutang.

1 Hasil Uji Asumsi Klasik

a. Hasil Uji Normalitas

Hasil uji normalitas pada penelitian ini ditunjukkan pada gambar 1 sebagai berikut:

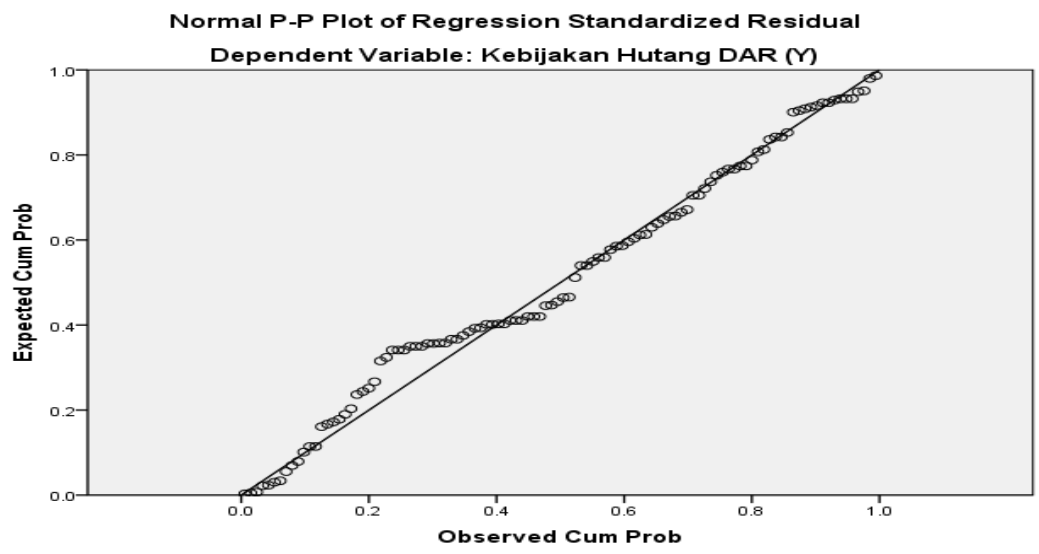

Gambar 1

P Plot Uji Normalitas kebijakan hutang di proxy DAR

Berdasarkan Gambar 4.1 diatas, Titik -titik plot membentuk suatu garis diagonal, maka dapat disimpulkan bahwa data terdistribusi secara normal.

b. Uji Multikolinieritas

Uji Multikolonieritas bertujuan untuk membuktikan atau menguji apakah dalam suatu model regresi ditemukan adanya korelasi antar variabel bebas (independen). Nilai cutoff yang umum dipakai untuk menunjukkan adanya multikolonieritas adalah nilai tolerance $<0,10$ atau sama dengan nilai VIF > 10 (Ghozali) dalam (Safitri, 2017.)

Tabel 3

Hasil Uji Multikolinieritas

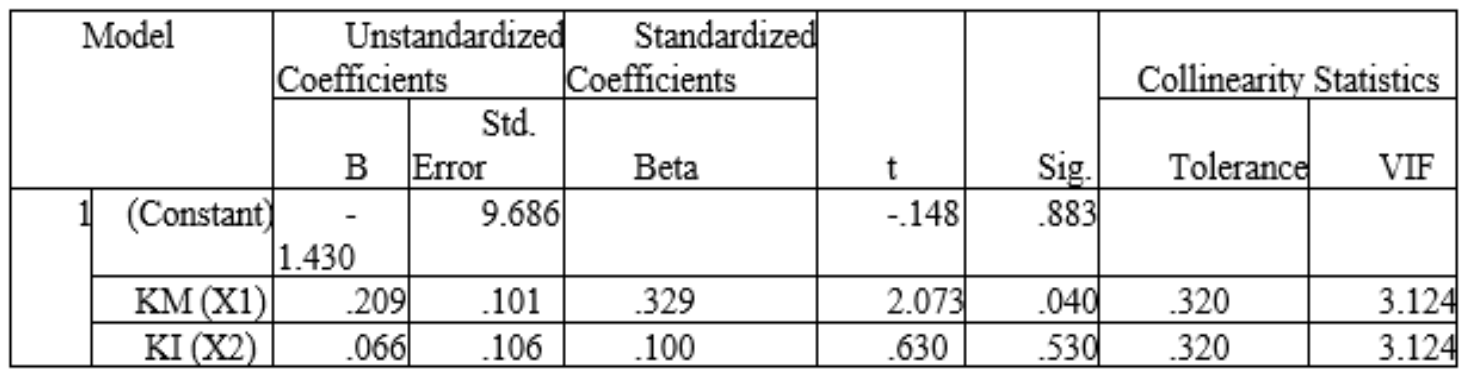

a. Dependent Variable: Kebijakan Hutang DAR(Y) 
Dari tabel 3 diatas dapat diperoleh informasi bahwa nilai tolerance KM dan KI sebesar 0,320 $>0,10$, dan nilai VIF dari KM dan KI sebesar 3,124<0,1. Berdasarkan hal tersebut maka dapat disimpulkan bahwa dalam persamaan regresi model penelitian ini dengan kebijakan hutang di proxy oleh DAR (debt to assets ratio) tidak terjadi gejala multikolinieritas.

c. Uji heterokedastisitas

Hasil uji heterokedastisitas dalam penelitian ini dapat dilihat pada gambar 2 sebagai berikut:

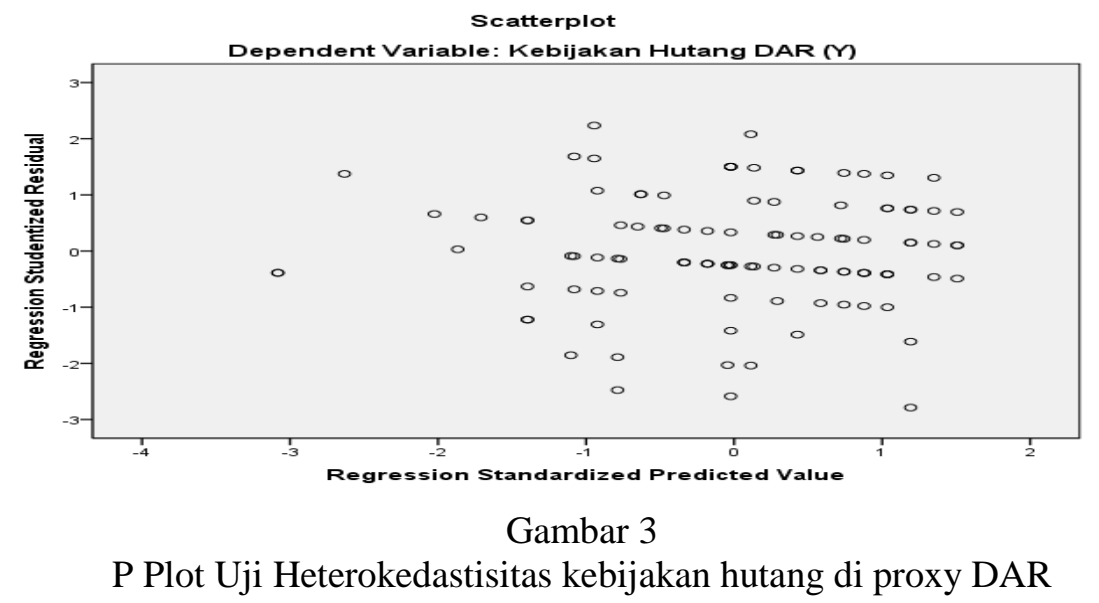

2 Hasil Pengujian Hipotesis

a. Uji R2 atau Koefisien Determinasi

Gozali (2017) koefisien determinasi pada intinya yaityu untuk mengukur seberapa jauh kemampuan model dalam menerangkan variasi variabel dependen. Nilai adjusted R-Square yang diperoleh dalam penelitian ini disajikan pada tabel 4.2 sebagai berikut :

Tabel 4

Hasil Uji R-Square (Model Summaryb)

\begin{tabular}{|c|c|c|c|c|}
\hline Model & & & & \\
& $\mathrm{R}$ & R Square & Adjusted R Square & Std. Error of the Estimate \\
\hline 1 & $.253 \mathrm{a}$ & .64 & .48 & 19.19446 \\
\hline
\end{tabular}

a. Predictors: (Constant), KM (X1), KI (X2)

b. Dependent Variable: Kebijakan Hutang DAR(Y)

Hasil analisis regresi berganda menunjukkan bila nilai adjusted $\mathrm{R}$ sebesar 0,48 atau $48 \%$ hasil ini menunjukkan bahwa sebesar $48 \%$ perubahan DAR dipenaruhi oleh Kepemilikan Manajerial dan kepemilikan Institusional, sedangkan selisihnya yaitu $100 \%-48 \%=52 \%$ dipengaruhi oleh faktor lain selain model penelitian.

Uji Model

Hasil uji model dalam penelitian ini, persamaan regresi yang diperoleh adalah sebagai berikut :

Tabel 5

Hasil Uji Model Persamaan Regresi (Coefficirntsa)

\begin{tabular}{|c|c|c|}
\hline Model & B & .Sig \\
\hline (Constant) & 1.430 & .883 \\
\hline KM & .209 & .040 \\
\hline KI & .066 & .030 \\
\hline
\end{tabular}

a. Dependent Variable: Kebijakan Hutang DAR(Y)

Model Persamaan Regresi linier berganda dalam penelitian ini dirumuskan bahwa $\mathrm{Y}=$ $\mathrm{a}+\mathrm{b} 1 \mathrm{X} 1+\mathrm{b} 2 \mathrm{X} 2+$ e Berdasarkan Tabel 4.3 diatas menunjukkan bahwa persamaan regresi DAR atau $\mathrm{Y}=1,43+0,209 \mathrm{X} 1+0,66 \mathrm{X} 2+\mathrm{e}$.

Uji t

Uji t digunakan untuk menguji signifikansi hubungan antara variabel $\mathrm{X}$ dan Y. Dalam penelitian ini uji $\mathrm{t}$ dilakukan untuk mengetahui ada tidaknya pengaruh antara kepemilikan 
manajerial dan kepemilikan institusional terhadap kebijakan hutang (yang di proxy oleh DAR). Hasil uji t dalam penelitian ini dapat dilihat dalam tabel 4.4 sebagai berikut:

Tabel 6

Hasil Uji t

\begin{tabular}{|l|l|l|l|l|}
\hline Variabel & Beta & t hitung & Nilai Signifikan & Keterangan \\
\hline Terhadap DAR & .209 & 2.073 & .040 & Berpengaruh signifikan positif \\
\hline KM (X1) & .066 & .630 & .030 & Berpengaruh signifikan positif \\
\hline KI (X2)
\end{tabular}

Berdasarkan tabel 6 diatas, maka dapat diperoleh beberapa informasi, yaitu: Koefisien regresi KM sebesar 0,209 Berarti hubungan KM dan DAR Positif, Jika KM naik maka DAR juga akan naik. Nilai signifikan KM sebesar 0,040 $<0,05$ berarti KM berpengaruh signifikan positif terhadap DAR. Koefisien regresi KI sebesar 0,066 Berarti hubungan KI dan DAR Positif, Jika KI naik maka DAR juga akan naik. Nilai signifikan KI sebesar 0,030<0,05 berarti KI berpengaruh signifikan positif terhadap DAR.

\section{PEMBAHASAN}

Pembahasan mengenai hasil penelitian serta informasi yang dapat diperoleh dari hasil penelitian ini adalah sebagai berikut :

H1 : Kepemilikan Manajerial Berpengaruh terhadap Kebijakan Hutang pada perusahaan Manufaktur yang terdaftar di Bursa Efek Indonesia pada tahun 2016,2017,2018,dan 2019.

Berdasarkan hasil analisis regresi berganda dengan tingkat signifikansi 0,05 maka diketahui bahwa variabel Kepemilikan Manajerial berpengaruh signifikan positif terhadap Kebijakan Hutang (yang diproxy oleh DAR), Hal ini mendukung hasil penelitian jorenza (2015), dan revi (2015).hasil penelitian ini tidak sama dengan penelitian Eva larasati (2016)

H2 : Kepemilikan Institusional Berpengaruh terhadap Kebijakan Hutang pada perusahaan Manufaktur yang terdaftar di Bursa Efek Indonesia pada tahun 2016, 2017, 2018, dan 2019.

Berdasarkan hasil analisis regresi berganda dengan tingkat signifikansi 0,05 maka diketahui bahwa variabel Kepemilikan Institusional berpengaruh signifikan positif terhadap Kebijakan Hutang (yang diproxy oleh DAR), Hal ini mendukung hasil penelitian jorenza (2015), dan revi (2015). Hasil penelitian ini tidak sama dengan penelitian niken anindhita (2017)

\section{KESIMPULAN}

Berdasarkan analisis data yang dilakukan dalam penelitian ini yaitu untuk mengetahui pengaruh kepemilikan manajerial dan kepemilikan institusional terhadap kebijakan hutang perusahaan manufaktur yang terfadtar di Bursa Efek Indonesia Tahun 2016, 2017, 2018 dan 2019, maka dapat disimpulkan beberapa hal. Kesimpulan dari penelitian ini yaitu:

Kepemilikan manajerial perusahaan manufaktur berpengaruh signifikan positif terhadap kebijakan hutang yang di dihung dengan rasio Debt to asset ratio (DAR). Hal ini mengindikasikan bahwa kepemililkan manajerial dipertimbangkan oleh pihak internal maupun pihak eksternal perusahaan dalam menentukan kebijakan hutang dan memiliki pengaruh yang positif terhadap kinerja perusahaan. Pada saat ini kepentingan manajerial digunakan sebagai pemilihan strategi analisis antar investor dan dengan pihak manajemen perusahaan yang ditanggapi positif oleh pasar.

Kepemilikan institusional perusahaan manufaktur berpengaruh signifikan positif terhadap kebijakan hutang yang di dihung dengan rasio Debt to asset ratio (DAR). Hal ini mengindikasikan bahwa kepemililkan institusional juga diperhitungkan oleh pihak manajemen perusahaan dalam menentukan kebijakan hutang yang akan di laksanakan perusahaan sebagai pendukung untuk peningkatan kinerja perusahaan.

\section{REFERENSI}

Niken, anindita. (2017). pengaruh kepemilikan saham institusi, saham publik, kebijakan deviden, struktur aset dan profitabilitas terhadap kebijakan hutang perusahaan manufaktur BEI . Jurnal Fekon, Vol.1 (2): 1389-1403. 
Alfinur. Pengaruh mekanisme good corporate governance (GCG) terhadap nilai perusahaan pada perusahaan yang listing di BEI. Jurnal Ekonomi Modernisasi JEM. Vol: 12 No. 1, pp: 4450.

Brigham, E.F., \& Weston, J.F. (1996). Dasar-Dasar Manajemen Keuangan. Jakarta: Erlangga.

Brigham, EF, and JF Houston. 2006. Manajemen Keuangan edisi bahasa Indonesia, edisi 10. Jakarta: Erlangga.

Eva, Larasati, (2017). Pengaruh kepemilikan manajerial, kepemilikan institusional dan kebijakan deviden terhadap kebijakan hutang perusahaan. Jurnal ekonomi bisnis. Vol. 16 (2): 103107

Indra E, Tjaelani. (2013). Kepemilikan manajerial dan institusional pengaruhnya terhadap kebijakan hutang pada perusahaan manufaktur di bursa efek Indonesia. Jurnal EMBA. Vol. 1 (3): 129-139

Riska, Putri, Handayani, Ratih, (2019). Pengaruh kepemilikan manajerial, kepemilikan institusional, deviden, pertumbuhan perusahaan, free cash flow, dan profitabilitas terhadap kebijakan hutang perusahaan. Jurnal Bisnis dan Akuntansi. Vol. 11(3): 189-207

Jorenza, Chiquita dan Marjam, M, (2015). Analisis kepemilikan manajerial, kebijakan hutang dan profitabilitas terhadap kebijakan deviden dan nilai perusahaan pada perusahaan manufaktur yang terdaftar di BEI. Jurnal EMBA. Vol. 3(1): 1141-1151

Revi mareta, dkk, (2015). Pengaruh kepemilikan manajerial, kebijakan deviden dan profitabilitas terhadap kebijakan hutang. Jurnal administrasi bisnis (JAB). Vol 22 (1): 1-9

Jensen dan Meckling.2001. Theory of the Firm: Managerial Behaviour, Agency Costs, and ownership structure. Journal of financial economy. Vol.3 No.4.305-360

Andika, Ivona, M. (2012). Kebijakan deviden, kepemilikan manajerial, kepemilikan institusional, profitabilitas, rresiko bisnis terhadap kebijakan hutang. Accounting analysis journal. Vol. 1(2): 1-6

Muhammad zulman hakim, dkk. (2019). Pengaruh profitabilitas, likuiditas, leverage, kepemilikan manajerial dan kepemilikan institusional terhadap financial distress. Competitive jurnal akuntansi dan keuangan. Vol 4 (1): 94-105

Rona Mesi, Narita, (2012). Analisis Kebijakan Hutang. Accounting analysis journal. Vol. 1(2): 16

Ronny dan Sudirgo, T. (2020). Faktor faktor yang mempengaruhi nilai perusahaan pada perusahaan manufaktur di BEI. Vol 2 (1): 270-278

Safitri, Lia dan Amanah lailatul. Pengaruh keputusan investasi, keputusan pendanaan, kebijakan dividend an kinerja keuangan terhadap nilai perusahaan. JIRA, Vol.3 No.9: 2014

Anggun P. Situmorang. Liputan6, perusahaan manufaktur jadi nomer 1 andalan di Indonesia/bisnis read/3 feb 2020,14:50

CNBC Indonesia. www. outlock 2019/cn.bclndosesia.com

Chandrarin, Grahita. 2017. Metode Riset Akuntansi Pendekatan Kuantitatif, Jakarta: Salemba Empat.

Palepu, Krishna dan Healy, Paul. 2014. Analisis dan Valuasi Bisnis berbasis IFRS, Jakarta: Salemba Empat.

Sugiyono. 2015. Metode Penelitian Bisnis, Bandung: Alfabeta. 